\title{
Movements, behavior and habitat preferences of juvenile white sharks Carcharodon carcharias in the eastern Pacific
}

\author{
Kevin C. Weng ${ }^{1, *}$, John B. O'Sullivan ${ }^{2}$, Christopher G. Lowe $^{3}$, Chuck E. Winkler ${ }^{4}$, \\ Heidi Dewar ${ }^{1}$, Barbara A. Block ${ }^{1}$ \\ ${ }^{1}$ Tuna Research and Conservation Center, Hopkins Marine Station of Stanford University, 120 Ocean View Boulevard, \\ Pacific Grove, California 93950-3024, USA \\ ${ }^{2}$ Monterey Bay Aquarium, 886 Cannery Row, Monterey, California 93940-1023, USA \\ ${ }^{3}$ California State University, Long Beach, Department of Biological Sciences, 1250 North Bellflower Boulevard, Long Beach, \\ California 90840-0004, USA \\ ${ }^{4}$ Southern California Marine Institute, 820 South Seaside Avenue, Terminal Island, California 90731-7330, USA
}

\begin{abstract}
Understanding of juvenile life stages of large pelagic predators such as the white shark Carcharodon carcharias remains limited. We tracked 6 juvenile white sharks (147 to $250 \mathrm{~cm}$ total length) in the eastern Pacific using pop-up satellite archival tags for a total of 534 d, demonstrating that the nursery region of white sharks includes waters of southern California, USA, and Baja California, Mexico. Young-of-the-year sharks remained south of Point Conception whereas one 3 yr old shark moved north to Point Reyes. All juvenile white sharks displayed a diel change in behavior, with deeper mean positions during dawn, day and dusk $(26 \pm 15 \mathrm{~m})$ than during night $(6 \pm 3 \mathrm{~m})$. Sharks occasionally displayed deeper nocturnal movements during full moon nights. On average, vertical excursions were deeper and cooler for $3 \mathrm{yr}$ olds $\left(226 \pm 81 \mathrm{~m} ; 9.2 \pm 0.9^{\circ} \mathrm{C}\right)$ than young-of-the-year animals $\left(100 \pm 59 \mathrm{~m} ; 11.2 \pm 1.4^{\circ} \mathrm{C}\right)$. Juvenile white sharks are captured as bycatch in both US and Mexican waters, suggesting that management of fishing mortality should be of increased concern.
\end{abstract}

KEY WORDS: Juvenile white shark · Carcharodon carcharias $\cdot$ Habitat $\cdot$ Diel behavior $\cdot$ Satellite tag · Bycatch

\section{INTRODUCTION}

The white shark Carcharodon carcharias is an apex predator with a cosmopolitan distribution in temperate and tropical waters of both hemispheres (Compagno 1984) and occurs rarely at boreal latitudes (Martin 2004). Recent advances in our understanding of adult white shark movements and habitat utilization have come through the use of electronic tag technologies. Shortterm acoustic tracks off North America have revealed that sharks prefer shallower depths (0 to $50 \mathrm{~m}$ ) on the continental shelf (Carey et al. 1982, Goldman et al. 1996, Goldman 1997, Klimley et al. 2001). Longer satellite tracks revealed that adult white sharks made large-scale pelagic movements from the coastal waters of California into the eastern and central Pacific as far west as Hawaii (Boustany et al. 2002). During these offshore excursions the white sharks occupied depths from the surface to $>980 \mathrm{~m}$ and encountered ambient temperatures from 4 to $24^{\circ} \mathrm{C}$. Satellite tracking of white sharks in South Africa (Bonfil et al. 2005) using fin-mounted Argos position tags also revealed coastal and pelagic movements, with one shark making an extensive trans-oceanic journey from South Africa to Western Australia.

Few studies have focused on the juvenile life stages of white sharks (Klimley et al. 2002, Dewar et al. 2004). Klimley et al. (2002) acoustically tracked a single youngof-the-year (YOY) white shark for $3.6 \mathrm{~h}$ near La Jolla, California. This shark made oscillatory movements between the surface and $25 \mathrm{~m}$ depth. Over this depth range 
the temperature dropped from 21 to $15^{\circ} \mathrm{C}$. Dewar et al. (2004) tracked an individual YOY white shark with a pop-up satellite tag for $28 \mathrm{~d}$ near Long Beach, California. This shark preferred mixed layer waters of 16 to $22^{\circ} \mathrm{C}$ but made frequent movements through the thermocline to temperatures as low as $9^{\circ} \mathrm{C}$ and depths of $240 \mathrm{~m}$. Neither animal moved out of the Southern California Bight (SCB), however both were tracked for short durations.

Little is known about the breeding, parturition and early life history phases of white sharks. Pregnant white sharks have been captured near Japan, Taiwan, Australia, New Zealand, in the Mediterranean, and off Kenya (Bruce 1992, Fergusson 1996, Francis 1996, Uchida et al. 1996, Anonymous 1999). YOY white sharks, having total lengths $<176 \mathrm{~cm}$ (Cailliet et al. 1985), have been observed in these regions as well as in the SCB and Baja California (Klimley 1985), the New York Bight (Casey \& Pratt 1985), southeastern Australia (Bruce 1992) and South Africa (Cliff et al. 1996). In the eastern Pacific, the nursery habitat is hypothesized to include the coast of North America south of Point Conception (Klimley 1985). YOY white sharks have been captured in commercial and recreational fisheries along this coast relatively close to shore (Klimley 1985), but no pregnant females have been captured in the region (Francis 1996), and the breeding and parturition locations for white sharks in the eastern Pacific remain unknown.

White sharks, like many large pelagic fishes and sharks, are under increasing fishing pressure (Stevens et al. 2000). The species is listed as 'vulnerable' by IUCN, the International Union for Conservation of Nature and Natural Resources (Fergusson et al. 2000) and is listed under Appendix II of CITES, the Convention on International Trade in Endangered Species (Inskipp \& Gillett 2005). Understanding the biology of both adult and juvenile white sharks is essential to the development of effective management strategies. The early life history stages of a low-fecundity species such as the white shark are particularly important, as fishing mortality is a more important factor in population dynamics than for a high fecundity species (Mollet \& Cailliet 2002). Juvenile white sharks are captured in commercial fisheries off California (Klimley 1985) and Baja California, Mexico (O. SosaNishizaki pers. comm.) and in this study we identify important habitats of juvenile white sharks in this region of the eastern Pacific.

\section{MATERIALS AND METHODS}

Satellite tagging of sharks. Pop-up satellite archival tags (PAT 2.0 and 4.0, Wildlife Computers, Redmond, WA, USA) were deployed on 6 juvenile white sharks during 2002 to 2004 (Table 1). The tags were programmed to archive data at 30 or $60 \mathrm{~s}$ intervals. The

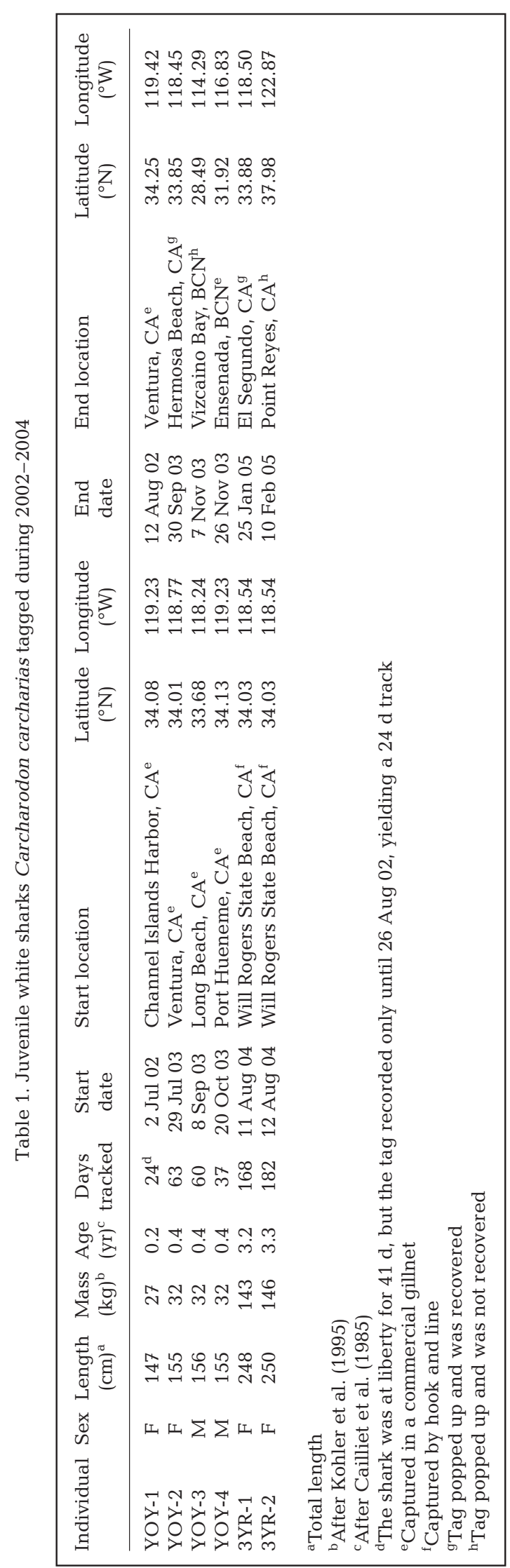


archival data were compressed into bins of 2, 6 or $12 \mathrm{~h}$ for transmission to Argos satellites. For each bin the tag produced a depth-temperature profile and 2 histograms, one of time-at-depth and one of time-at temperature. In addition, a dawn and dusk light curve was transmitted for each day.

Tags were deployed in the SCB on white sharks that were captured in bottom-set gillnets as bycatch (Table 1). Each PAT was attached to a titanium dart $(59 \mathrm{~mm} \times 13 \mathrm{~mm})$ with a $15 \mathrm{~cm}$ segment of $136 \mathrm{~kg}$ monofilament line (300 lb test Extra-hard Hi-catch, Momoi) covered with shrink-wrap (Block et al. 1998). The dart was cleaned with Betadine microbicide (Purdue Pharma) and inserted into the dorsal musculature at the base of the first dorsal fin using a stainless steel applicator, such that the satellite tag trailed behind the fin. To ease the insertion of the dart, a small slit in the skin was made using a surgical scalpel.

We obtained data from all 6 of the white sharks tagged. Four PAT tags were recovered after releasing from sharks or when sharks were recaptured, providing full archival records of depth, temperature and light, while the 2 remaining tags transmitted summary data (Table 1).

Estimation of geopositions. To determine the movements of each shark between the start and end positions, longitude was calculated from light levels (Hill \& Braun 2001) using software provided by the manufacturer (WC-GPE version 1.01.0005) and latitude was estimated by matching sea surface temperature (SST) measured by the tag to SST measured by satellites along the estimated longitude (Smith \& Goodman 1986, Teo et al. 2004) using MatLab (MathWorks). A speed filter of $2.7 \mathrm{~km} \mathrm{~h}^{-1}$ was used to filter the position data, based on the speed for a juvenile white shark obtained during an acoustic track by Klimley et al. (2002). Given that this shark would travel $2.7 \mathrm{~km} \mathrm{~h}^{-1}$ if it made no turns or vertical movements, this speed filter is conservative.

Potential errors in geolocation were estimated by comparing known deployment or endpoint locations to estimated geolocations within $1 \mathrm{~d}$. For error calculations, the geolocation algorithm was run with no limit on daily movements rates so that there would be no confounding effects of the speed filter.

Quantification of vertical and thermal habitat preferences. The depth and temperature habitats of the sharks were described using pressure and temperature data collected by the tags, and characterized in terms of the surface mixed layer and thermocline. Ideally, surface mixed layer depth is calculated according to density, but since our tags do not measure salinity, we used a definition of $\Delta 1^{\circ} \mathrm{C}$ from the surface (Rao et al. 1989). This depth was used to calculate the average temperature of the surface mixed layer and the ther- mocline. Time spent within the surface mixed layer and the thermocline was calculated for individuals with archival records (Sharks YOY-1, YOY-2, YOY-4 and 3YR-1); for transmitted records, bin margins for the time-at-depth histograms typically did not correspond to the surface mixed layer depth, so similar calculations were not performed. However, in the case of Shark 3YR-2, a time-at-temperature histogram bin $\left(20^{\circ} \mathrm{C}\right)$ corresponded closely to the mixed layer temperature in the summer and autumn $\left(19.8^{\circ} \mathrm{C}\right)$ and a time-at-depth bin $(50 \mathrm{~m})$ corresponded closely to the winter mixed layer depth $(55 \pm 1 \mathrm{~m})$, so these values were used.

Quantification of diel differences in depth and temperature. To investigate diel patterns in habitat preferences, we used the light record in archival records to divide the $24 \mathrm{~h}$ cycle into dawn, day, dusk and night periods and then determined depth and temperature preferences within these 4 periods, using MatLab. The light record was corrected for light attenuation with depth using the following light attenuation relationship:

$$
L_{Z}=L_{\mathrm{s}} \mathrm{e}^{-K Z}
$$

where $Z$ is the depth, $L_{\mathrm{s}}$ is the light at the surface, $L_{Z}$ is the light measured by the tag at depth $Z$, and $K$ is the light attenuation coefficient. To allow the use of a threshold value to separate twilight from day (or night), between-day variation in $L_{\mathrm{s}}$ was removed as follows:

$$
L_{\mathrm{sc}}=L_{\mathrm{s}}-\overline{\left(L_{\mathrm{s}}\right)_{W}}
$$

where $w$ is the width of the moving average of $L_{\mathrm{s}}$, set to the number of records per day. $L_{\mathrm{sc}}$ is then $L_{\mathrm{s}}$ without interdiel trend and centered about zero. We defined the periods of the diel cycle as follows:

$$
\begin{aligned}
& \text { dawn: } \frac{\Delta L_{\mathrm{s}}}{\Delta t} \geq G_{\mathrm{dn}} \\
& \text { day: }\left(\frac{\Delta L_{\mathrm{s}}}{\Delta t}<G_{\mathrm{dn}}\right) \wedge\left(\frac{\Delta L_{\mathrm{s}}}{\Delta t}>G_{\mathrm{dk}}\right) \wedge\left(L_{\mathrm{s}}>L_{\mathrm{d}}\right) \\
& \text { dusk: } \frac{\Delta L_{\mathrm{s}}}{\Delta t} \leq G_{\mathrm{dk}} \\
& \text { night: }\left(\frac{\Delta L_{\mathrm{s}}}{\Delta t}<G_{\mathrm{dn}}\right) \wedge\left(\frac{\Delta L_{\mathrm{s}}}{\Delta t}>G_{\mathrm{dk}}\right) \wedge\left(L_{\mathrm{s}}<-L_{\mathrm{d}}\right)
\end{aligned}
$$

where $t$ is time, $G_{\mathrm{dn}}=\frac{\Delta L_{\mathrm{s}}}{\Delta t}$ during dawn, $G_{\mathrm{dk}}=\frac{\Delta L_{\mathrm{s}}}{\Delta t}$ during dusk, and $L_{\mathrm{d}}$ is the minimum $L_{\mathrm{s}}$ during the day.

We conducted an analysis to determine if the light of the moon affected the vertical distribution of juvenile white sharks during nighttime periods. We selected nighttime depths based on the light level measured by the tag, as described above, and within these data 
compared $3 \mathrm{~d}$ periods centered on the full moon with $3 \mathrm{~d}$ periods centered on the new moon, as determined from astronomical tables (Anonymous 2006).

\section{RESULTS}

\section{Geographic movements}

Six juvenile white sharks were tagged and released in the Southern California Bight (SBC) between July 2002 and August 2004, and moved within waters offshore of California and Baja California, Mexico (Fig. 1). Young-of-the-year (YOY) sharks were tracked for $46 \pm 19 \mathrm{~d}$ (184 d in total) while $3 \mathrm{yr}$ old sharks were tracked for $175 \pm 10 \mathrm{~d}$ (350 d in total) (Table 1). The ranges of YOY and $3 \mathrm{yr}$ old sharks overlapped in the SCB but YOY sharks traveled further south, and $3 \mathrm{yr}$ old sharks moved further north. The 2 YOY sharks for which we have data in the summer and early autumn (Sharks YOY-1 and YOY-2) remained within the SCB for the duration of their tracks (July and August to September, respectively). Shark YOY-1 was recaptured near Ventura, California and Shark YOY-2's satellite tag popped up near Hermosa Beach, California. The remaining YOY sharks were tracked during autumn and traveled south into Mexican waters. Shark YOY-3 moved from the SCB to Vizcaino Bay, Baja California between late September and mid October, traveling $700 \mathrm{~km}$. Shark YOY-4 left the SCB during late November and was captured near Ensenada shortly thereafter. The 3 yr old sharks were tracked during autumn and winter (Table 1). Shark 3YR-1 was tagged off the $\mathrm{SCB}$ and remained within the SCB and waters off northern Baja California for the $168 \mathrm{~d}$ of the track. The satellite tag popped up near El Segundo, California on 25 January 2005. Shark 3YR-2 remained in the SBC and waters off northern Baja California from August to October and then moved north of Point Conception during the first $9 \mathrm{~d}$ of November 2004. During the remainder of the $182 \mathrm{~d}$ track the individual inhabited waters off central and northern California, and the tag released near Point Reyes on 25 January 2005, 600 km from the tagging location and $4^{\circ}$ farther north.

\section{Accuracy of geolocations}

Of the 6 sharks tagged in this study, light and SST geolocation estimates were obtained within $1 \mathrm{~d}$ of the start and end points for 6 of 12 possible pop-up endpoint events (Fig. 2). For these 6 events, the longitude errors ranged from $80 \mathrm{~km}$ west to $103 \mathrm{~km}$ east, with absolute error values averaging $54 \pm 36 \mathrm{~km}$ (mean \pm $\mathrm{SD}$ ). Latitude errors were all south, ranging from 17 to $434 \mathrm{~km}$, with an average of $231 \pm 159 \mathrm{~km}$.

\section{Vertical movements and diel patterns in behavior}

Juvenile white sharks showed strong diel patterns in behavior. During summer and autumn, when data were available for all 4 individuals with archival records (Sharks YOY-1, YOY-2, YOY-4, 3YR-1) mean
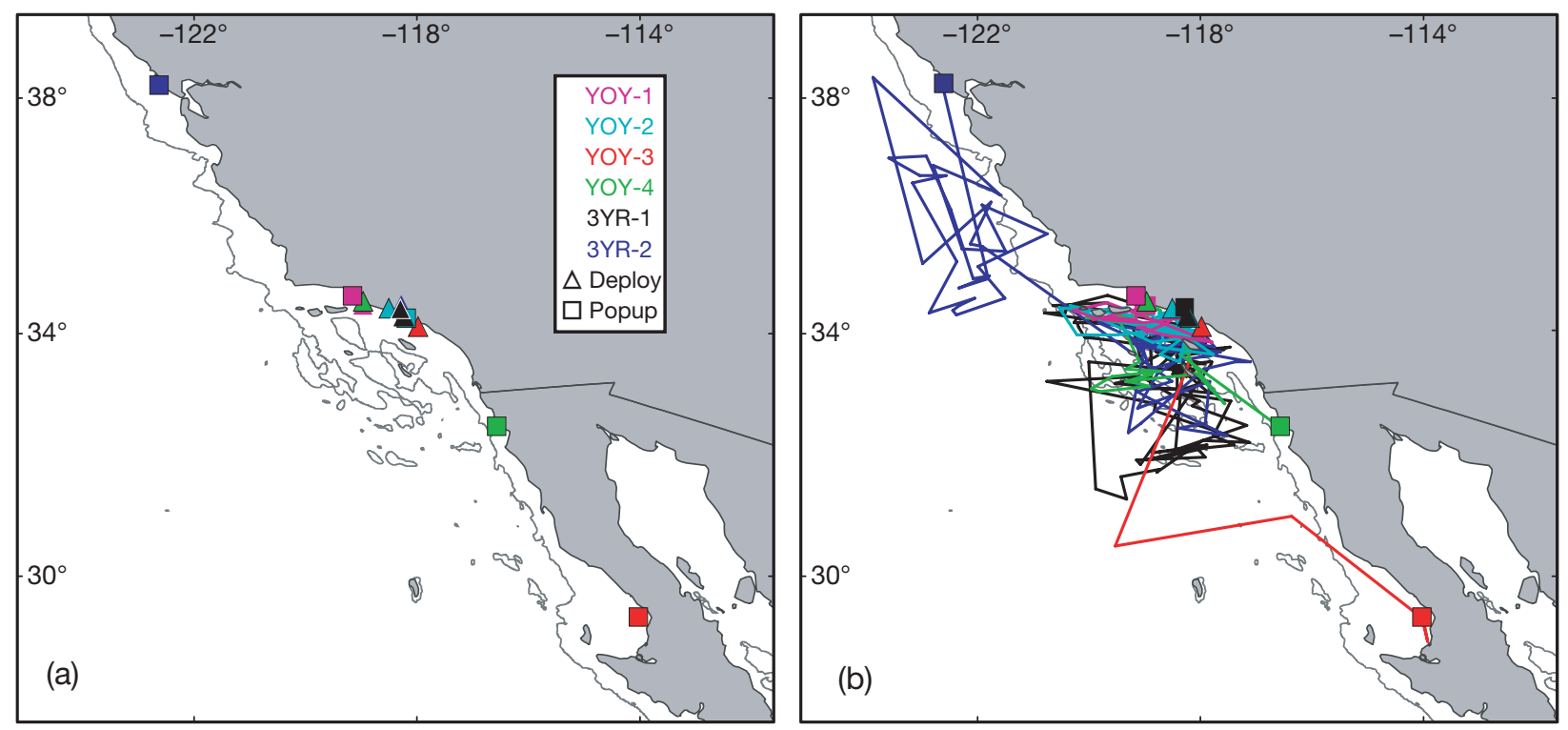

Fig. 1. Carcharodon carcharias. (a) Start and end positions for juvenile white sharks tracked off southern California, USA and Baja California, Mexico. (b) Daily positions of juvenile white sharks based on light- and SST-based geolocations. Grey line: $1000 \mathrm{~m}$ depth contour 


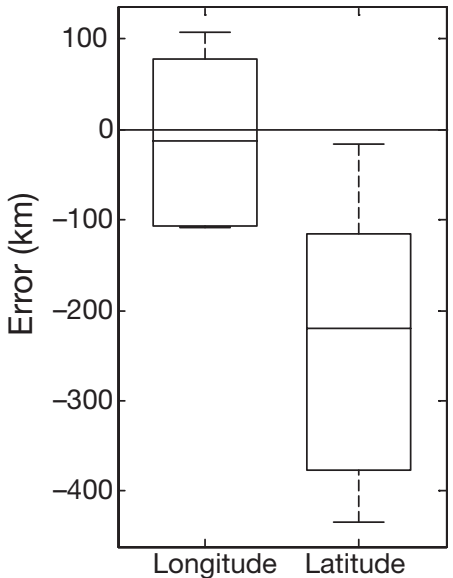

Fig. 2. Carcharodon carcharias. Error estimates for light- and SST-based geolocations for 6 juvenile white sharks. Positive values represent east and north; negative values west and south. Boxplots: centerline, median; edges of box, 1st and 3rd quartiles; whiskers, data points within the range Q1 - 1.5 $(\mathrm{Q} 3-\mathrm{Q} 1)$ to $\mathrm{Q} 3+1.5(\mathrm{Q} 3-\mathrm{Q} 1)$

depths were within the thermocline during dawn $(31 \pm$ $19 \mathrm{~m})$, day $(26 \pm 16 \mathrm{~m})$ and dusk $(22 \pm 10 \mathrm{~m})$ but in the surface mixed layer at night $(6 \pm 3 \mathrm{~m})$ (Figs. $3 \& 4)$; these depths were significantly shallower at night than during other periods of the day (paired $t$-tests, $\mathrm{p}<0.05$; Table 2). Consequently, the mean ambient temperatures were cooler during dawn $\left(15.8 \pm 0.4^{\circ} \mathrm{C}\right)$, day $\left(16.8 \pm 0.4^{\circ} \mathrm{C}\right)$ and dusk $\left(16.6 \pm 0.3^{\circ} \mathrm{C}\right)$ than during night $\left(18.2 \pm 0.4^{\circ} \mathrm{C}\right)$ (Figs. $\left.5 \& 6\right)$. These temperatures were significantly warmer during night than during other periods of the day; in addition, dawn was significantly cooler than day and dusk (paired $t$-tests, $\mathrm{p}<$ 0.05 ; Table 2). During winter, archival data were only available for Shark 3YR-1 and it showed no diel patterns in depth or temperature. The individual remained at a depth of $4 \pm 1 \mathrm{~m}$ and a temperature of 15.5 $\pm 0.1^{\circ} \mathrm{C}$, which was in the surface mixed layer.

In addition to comparing the average depths and temperatures between periods of the day, we compared the distributions of time-at-depth and time-attemperature between the 4 diel periods by summarizing these variables into evenly spaced depth and temperature bins. The same diel patterns emerged for all 4 sharks. During summer and autumn, when data were available for all 4 sharks, the shallower (Figs. 3 \& 4) and warmer (Figs. 5 \& 6) nighttime distributions were significantly different from other periods of the diel cycle ( $\mathrm{p}<0.05$, Kolmogorov-Smirnov tests, Table 3). A secondary peak of occupancy at depth occurred during dawn, day and dusk for all 4 individuals, though the depth of this secondary peak was shallower for YOY sharks $(47 \pm 23 \mathrm{~m})$ than for the $3 \mathrm{yr}$ old $(240 \mathrm{~m})$. Shark 3YR-2 had a secondary peak in the 200 to $300 \mathrm{~m}$ bin, showing agreement with the archival data for Shark 3YR-1. This secondary peak of occupancy caused a secondary peak in temperature occupancy during dawn, day and dusk, at $12.8 \pm 1.9^{\circ} \mathrm{C}$ for YOY sharks and $9.7 \pm 0.3^{\circ} \mathrm{C}$ for the 3 yr old shark. Dur-
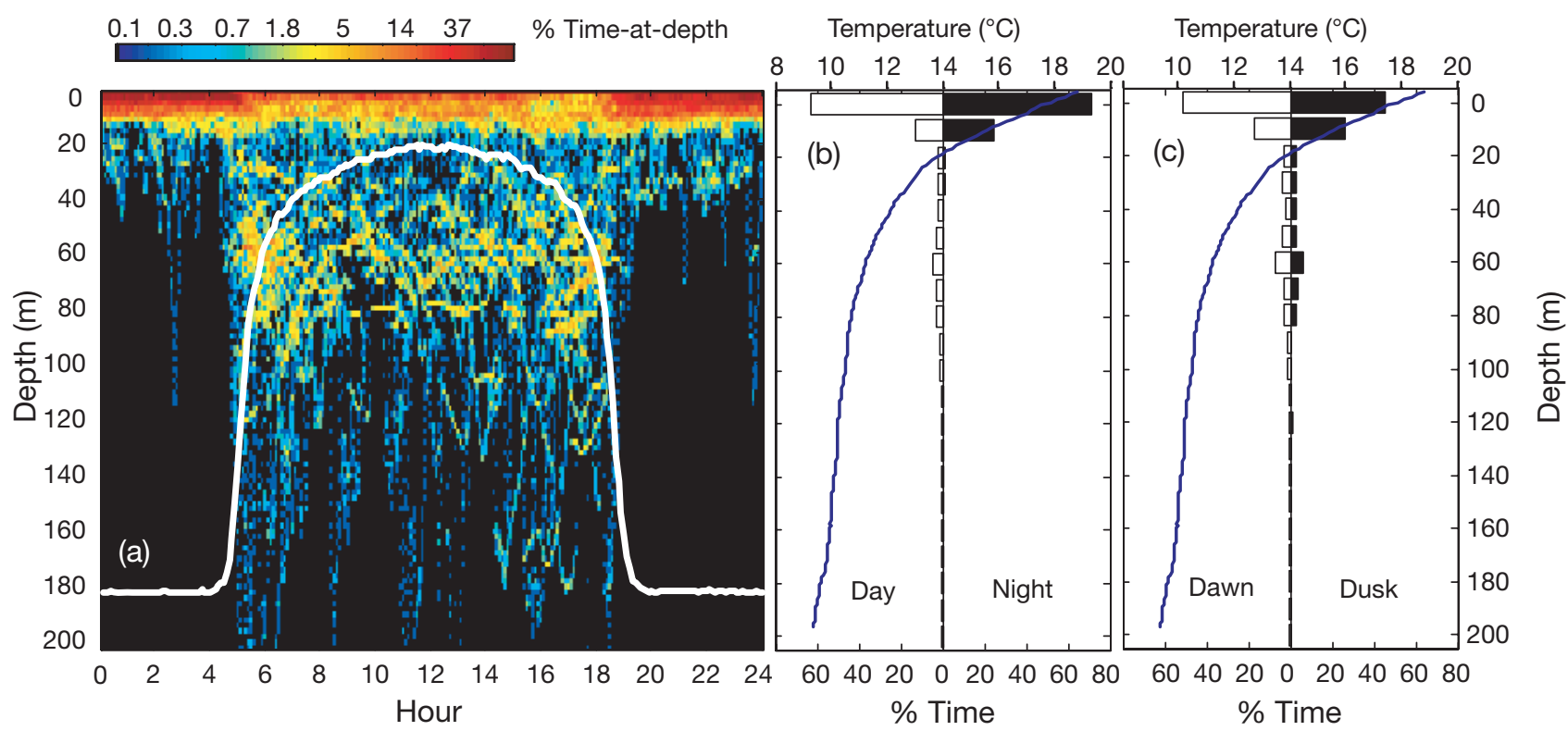

Fig. 3. Carcharodon carcharias. Diel changes in vertical movements for one young-of-the-year white shark (YOY-2). (a) Time-atdepth through $24 \mathrm{~h}$ cycle during summer in the Southern California Bight. Color denotes amount of time spent at each depth. White line: light intensity at the surface in arbitrary units. Time-at-depth histograms for (b) day and night and (c) dawn and dusk. Blue lines: depth-temperature profile 


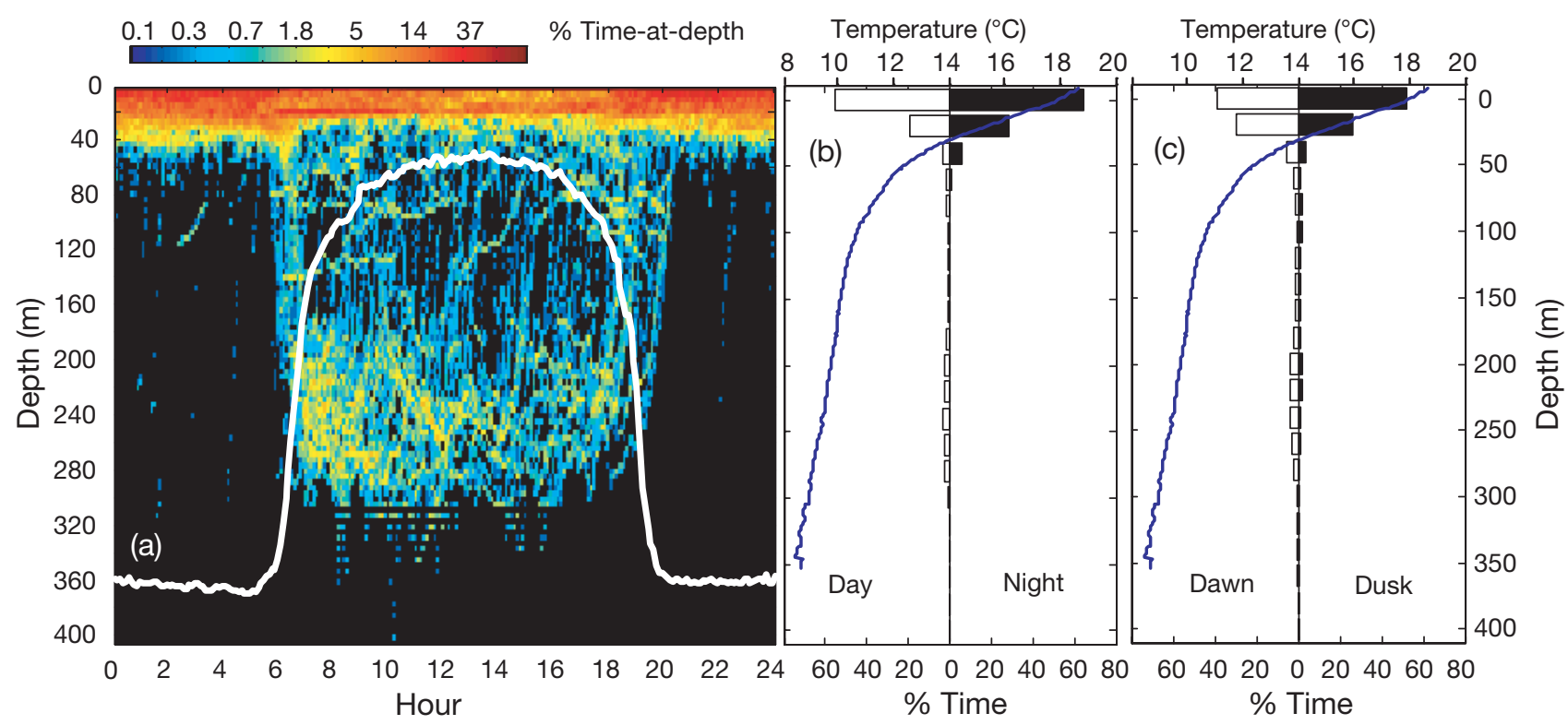

Fig. 4. Carcharodon carcharias. Diel changes in vertical movements for one 3 yr old white shark (3YR-1). (a) Time-at-depth through $24 \mathrm{~h}$ cycle during autumn in the Southern California Bight. Color denotes amount of time spent at each depth. White line: light intensity at the surface in arbitrary units. Time-at-depth histograms for (b) day and night and (c) dawn and dusk. Blue lines: depth-temperature profile
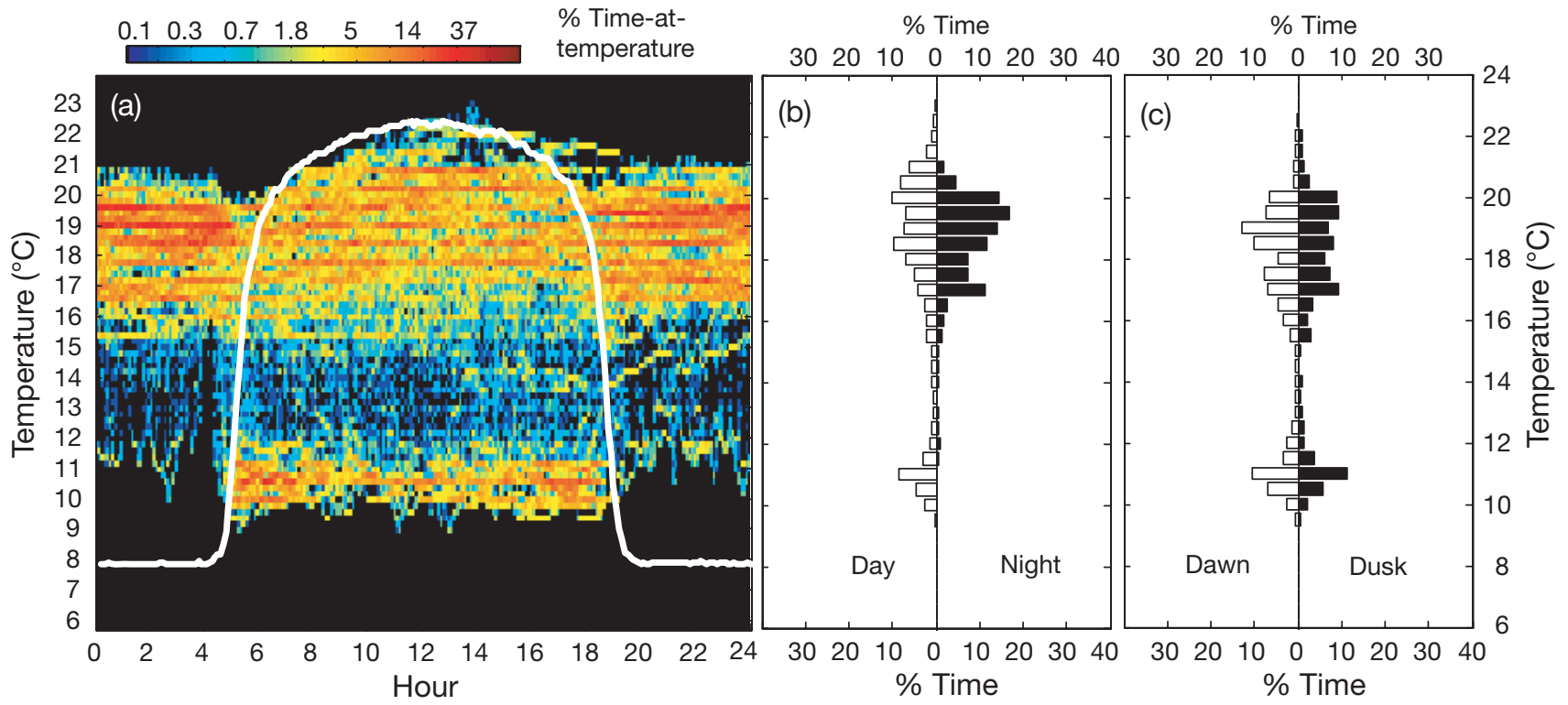

Fig. 5. Carcharodon carcharias. Diel changes in temperature preferences for a young-of-the-year white shark (YOY-2). (a) Timeat-temperature through $24 \mathrm{hr}$ diel cycle during summer in the Southern California Bight. Color denotes amount of time spent at each temperature. White line: light intensity at the surface in arbitrary units. Time-at-temperature histograms for (b) day and night and (c) dawn and dusk

ing winter, archival data were available only for shark 3YR-1, and this individual showed neither diel patterns nor a secondary peak of occupancy in the thermocline.

During the course of their tracks, the 3 YOY sharks undertook 2493 vertical excursions below the surface mixed layer, while the 3 yr old shark (Shark 3YR-1) undertook 1751 vertical excursions. The frequency and duration of these vertical excursions did not differ markedly between YOY and 3 yr old sharks, while the mean depth of excursions was shallower for the YOY animals. YOY sharks made $21 \pm 9$ vertical excursions per day, while Shark 3YR-1 made $20 \pm 11$ vertical excursions per day, and the difference was not significant (paired $t$-test, $\mathrm{p}=0.69$ ). The duration of excursions be- 

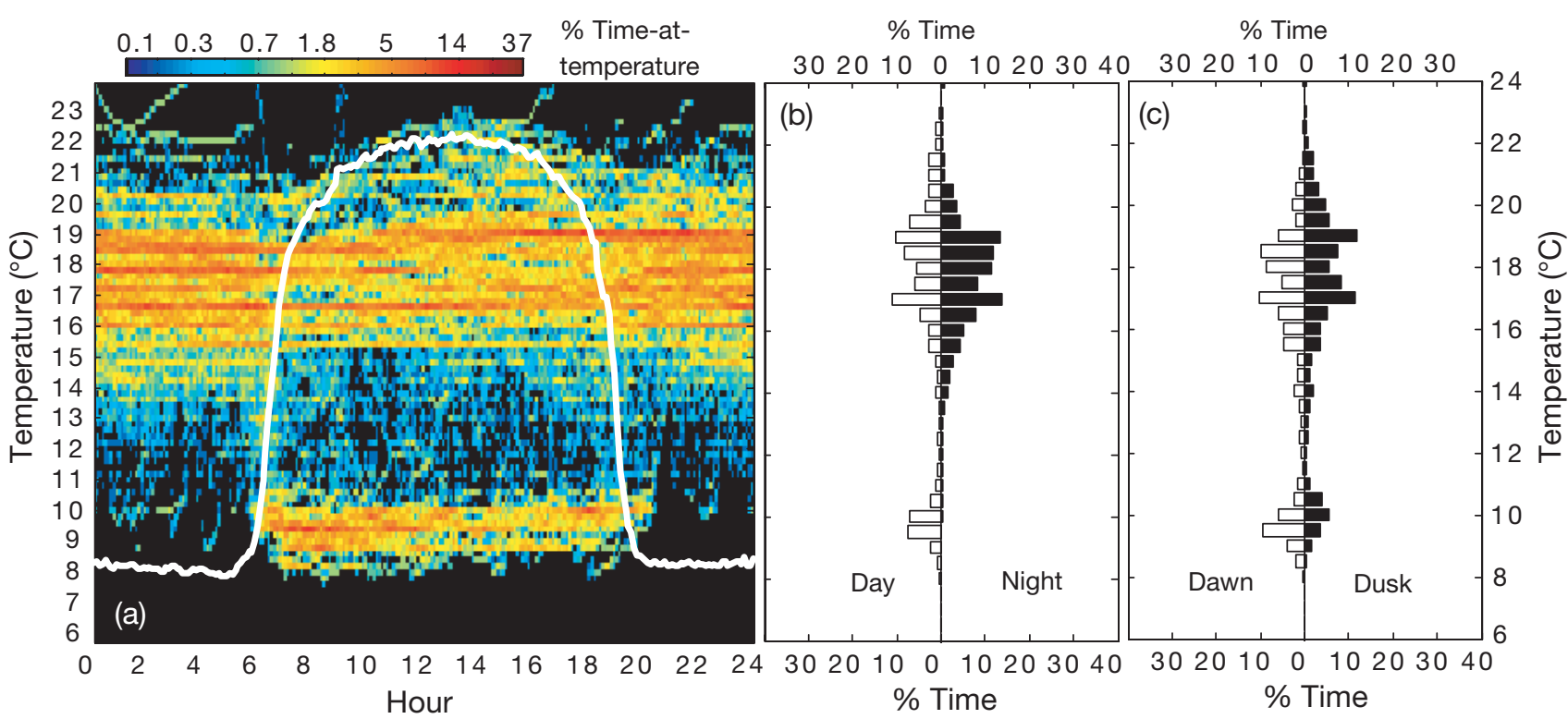

Fig. 6. Carcharodon carcharias. Diel changes in temperature preferences for a 3 yr old white shark (3YR-1). (a) Time-at-temperature through $24 \mathrm{hr}$ diel cycle during autumn in the Southern California Bight. Color denotes amount of time spent at each temperature. White line: light intensity at the surface in arbitrary units. Time-at-temperature histograms for (b) day and night and (c) dawn and dusk

Table 2. P-values from paired $t$-tests on data for Sharks YOY-1, YOY-2, YOY-3 and 3YR-1 during summer and autumn for average depth and temperature during diel periods. ${ }^{*}$ : statistically significant

\begin{tabular}{|lcccccc|}
\hline Test & $\begin{array}{c}\text { Dawn } \\
\text { vs. night }\end{array}$ & $\begin{array}{c}\text { Day } \\
\text { vs. night }\end{array}$ & $\begin{array}{c}\text { Dusk } \\
\text { vs. night }\end{array}$ & $\begin{array}{c}\text { Dawn } \\
\text { vs. day }\end{array}$ & $\begin{array}{c}\text { Dawn } \\
\text { vs. dusk }\end{array}$ & $\begin{array}{c}\text { Dusk } \\
\text { vs. day }\end{array}$ \\
\hline Depth $(\mathrm{a}>\mathrm{b})$ & $0.04^{*}$ & $0.05^{*}$ & $0.03^{*}$ & 0.36 & 0.22 & 0.66 \\
Temperature $(\mathrm{a}<\mathrm{b})$ & $0.00^{*}$ & $0.00^{*}$ & $0.00^{*}$ & $0.01^{*}$ & $0.00^{*}$ & 0.24 \\
\hline
\end{tabular}

mum temperatures were significantly cooler during dawn, day and dusk $\left(10.2 \pm 1.1^{\circ} \mathrm{C}\right)$ than during night $(12.2 \pm$ $1.7^{\circ} \mathrm{C}$ ) (paired $t$-test, $\mathrm{p}=0.05$ ). There was a strong contrast in the depth of excursions into the thermocline between age classes, with YOY sharks having significantly shallower excursions (100 $\pm 59 \mathrm{~m})$ than the 3 yr old shark $(226 \pm 81$ $\mathrm{m})$ (paired $t$-test, $\mathrm{p}=0.02$ ). The $3 \mathrm{yr}$ old

Table 3. P-values from Kolmogorov-Smirnov tests for distributions of time-at-depth and time-at-temperature during diel periods. ${ }^{*}$ : statistically significant

\begin{tabular}{|lllll|}
\hline Shark & Variable & $\begin{array}{c}\text { Dawn } \\
\text { vs. night }\end{array}$ & $\begin{array}{c}\text { Day } \\
\text { vs. night }\end{array}$ & $\begin{array}{c}\text { Dusk } \\
\text { vs. night }\end{array}$ \\
\hline YOY-1 & Depth & 0.155 & 0.797 & 0.797 \\
YOY-2 & Depth & $0.000^{*}$ & $0.000^{*}$ & $0.000^{*}$ \\
YOY-4 & Depth & $0.000^{*}$ & $0.000^{*}$ & $0.000^{*}$ \\
3YR-1 autumn & Depth & $0.000^{*}$ & $0.000^{*}$ & $0.001^{*}$ \\
3YR-1 winter & Depth & 1.000 & 1.000 & 1.000 \\
\hline
\end{tabular}

low the surface mixed layer was similar for YOY sharks $(0.7 \pm 1.3 \mathrm{~h})$ and the $3 \mathrm{yr}$ old shark $(0.8 \pm 1.5 \mathrm{~h})$ (paired $t$-test, $\mathrm{p}=0.30$ ). However, the duration of the longest excursion during each day was significantly greater for the 3 yr old shark $(5.1 \pm 3.0 \mathrm{~h})$ than the YOY sharks $(3.9 \pm$ $3.2 \mathrm{~h}$ ) (paired $t$-test, $\mathrm{p}=0.01$ ). Maximum depths were greater during dawn, day and dusk $(157 \pm 80 \mathrm{~m})$ than during night $(56 \pm 40 \mathrm{~m})$ for the 4 individuals with archival records (paired $t$-test, $\mathrm{p}<0.01$ ) (Fig. 7). Mini- shark reached significantly cooler temperatures during excursions into the thermocline $\left(9.2 \pm 0.9^{\circ} \mathrm{C}\right)$ than the YOY sharks $\left(11.2 \pm 1.4^{\circ} \mathrm{C}\right)$ (paired $t$-test, $\left.\mathrm{p}<0.01\right)$. The greatest depth and coolest temperature reached by each individual during its track was deeper and cooler for $3 \mathrm{yr}$ olds $\left(394 \pm 14 \mathrm{~m} ; 8.4 \pm 0.3^{\circ} \mathrm{C}\right)$ than for YOY animals $\left(241 \pm 82 \mathrm{~m} ; 9.4 \pm 0.6^{\circ} \mathrm{C}\right)$ (paired $t$-test for depth, $\mathrm{p}=0.02$; paired $t$-test for temperature, $\mathrm{p}=0.03$ ).

We compared nighttime depths between full moon and new moon periods (Fig. 8). The median nighttime depths were greater during full moon periods than new moon periods for 3 of the 4 sharks (Sharks YOY-2, YOY-4, 3YR-1). For Sharks YOY-2, YOY-4 and 3YR-1, nighttime full moon depths $(7 \pm 4 \mathrm{~m})$ were significantly greater than nighttime new moon depths $(3 \pm 2 \mathrm{~m})$ (Wilcoxon rank sum tests, $\mathrm{p}<0.05$ ). Shark YOY-1 did not show greater nighttime depths during full moon periods.

Potential benthic foraging events, as indicated by vertical excursions to consistent or gradually changing bottom depths (Fig. 8b), were noted on $63 \pm 10 \%$ of all days for which archival data were obtained (Sharks 


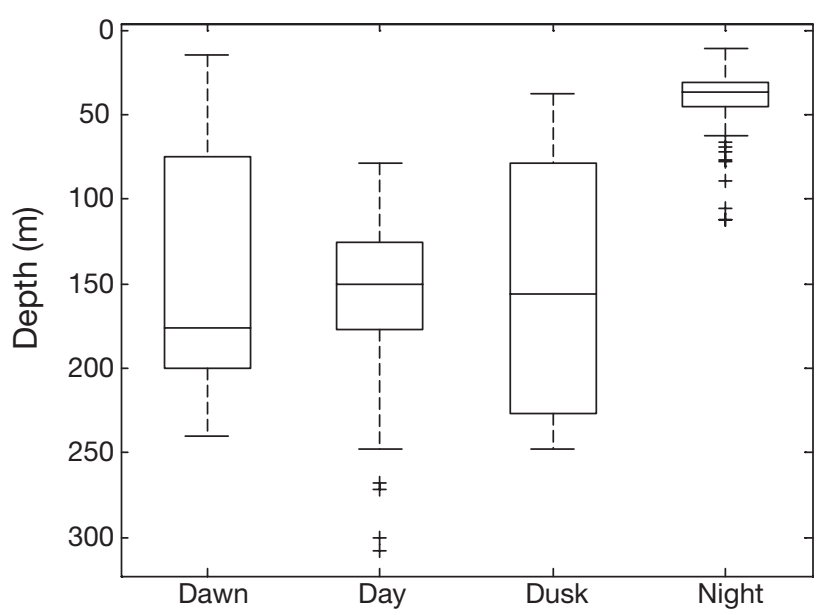

Fig. 7. Carcharodon carcharias. Maximum depths during dawn, day, dusk and night for a juvenile white shark (YOY-2). Boxplots: centerline, median; edges of box, 1st and 3rd quartiles; whiskers, data points within the range Q1 - 1.5 (Q3 - Q1)

to $\mathrm{Q} 3+1.5(\mathrm{Q} 3-\mathrm{Q} 1)$; +: points lying outside this range

YOY-1, YOY-2, YOY-4 and 3YR-1). YOY sharks undertook benthic foraging on $67 \pm 3 \%$ of all days, compared to $48 \%$ for the 3 yr old shark. The value for Shark 3YR1 remained the same if the comparison was conducted during summer and autumn only.

\section{Depth and temperature preferences}

The pressure and temperature data recorded on the PAT tag enabled reconstruction of the vertical thermal structure along the tracks of the sharks (Fig. 9). YOY sharks occupied waters with surface temperatures ranging from 15.0 to $23.4^{\circ} \mathrm{C}$, and the surface mixed layer had an average depth of $8 \pm 2 \mathrm{~m}$ (mean $\pm \mathrm{SD}$ ) and an average temperature of $18.8 \pm 0.2^{\circ} \mathrm{C}$. Below the surface mixed layer, waters occupied by YOY sharks averaged $13.8 \pm 1.7^{\circ} \mathrm{C}$. YOY sharks spent $64 \pm 19 \%$ of their time in the surface mixed layer and $36 \pm 19 \%$ of their time in the thermocline. Temperatures encountered by YOY sharks ranged from $23.4^{\circ} \mathrm{C}$ (Shark YOY-2) to $8.6^{\circ} \mathrm{C}$ (Shark YOY-3).

Three year old sharks (Sharks 3YR-1 and 3YR-2) inhabited waters similar to those of YOY sharks during the summer and autumn, spending $53 \pm 0 \%$ of the time in the surface mixed layer with an average depth of $9 \pm$ $0 \mathrm{~m}$ and an average temperature of $19.2 \pm 0.8^{\circ} \mathrm{C}$, and $47 \pm 0 \%$ of the time in thermocline waters averaging $13.4 \pm 1.6^{\circ} \mathrm{C}$. During the winter (December to February) the 3 yr old sharks spent $93 \pm 9 \%$ of their time in a deeper, colder surface mixed layer averaging $45 \pm$ $15 \mathrm{~m}$ and $14.3 \pm 1.8^{\circ} \mathrm{C}$; and $7 \pm 9 \%$ of their time in the thermocline in average temperatures of $13.0 \pm 0.1^{\circ} \mathrm{C}$. Temperatures encountered by 3 yr old sharks ranged from $24.0^{\circ} \mathrm{C}$ (Shark 3YR-2) to $8.4^{\circ} \mathrm{C}$ (Shark 3YR-1).

The depth and temperature distributions of the juvenile white sharks showed differences between YOY and 3 yr old age classes. YOY sharks inhabited temperatures below $10^{\circ} \mathrm{C}$ only $1 \pm 2 \%$ of the time, compared to $10 \pm 1 \%$ of the time for 3 yr old sharks during the same seasons (paired $t$-test, $\mathrm{p}<0.01$ ).

\section{Seasonal patterns of mixed layer occupancy and maximum depth}

Vertical and thermal habitats were compared across seasons (autumn and winter) for the $3 \mathrm{yr}$ old sharks that were tracked into the winter months. For Sharks 3YR-1 and 3YR-2 a seasonal cooling of the mixed layer in winter, as well as during movements north of Point Conception, coincided with a near cessation of vertical movements into the thermocline resulting in a constriction of the habitat to the surface mixed layer (Fig. 10). During summer and autumn, when mixed layer temperatures averaged $19.2 \pm 0.8^{\circ} \mathrm{C}$, both sharks frequently made excursions to depths $>300 \mathrm{~m}$, where water temperatures averaged $13.4 \pm$ $1.6^{\circ} \mathrm{C}$, and spent $18 \pm 2 \%$ of the time in waters cooler than $12^{\circ} \mathrm{C}$; calculation of time within thermocline waters was not possible for shark 3YR-2, so $12^{\circ} \mathrm{C}$ was used as a threshold instead. During winter, when mixed layer temperatures averaged $14.3 \pm 1.8^{\circ} \mathrm{C}$, the 2 sharks avoided thermocline waters even though the temperature of this layer $\left(13.0 \pm 0.1^{\circ} \mathrm{C}\right)$ was similar to its temperature during summer and autumn, spending only $0.4 \pm 0.0 \%$ of the time in waters cooler than $12^{\circ} \mathrm{C}$ (paired $t$-test, $\mathrm{p}=0.05)$. The maximum depth reached by the sharks was positively
Fig. 8. Carcharodon carcharias. Vertical movements of a juvenile white shark (YOY-2) for two $48 \mathrm{~h}$ periods during (a) full moon, (b) new moon. Lines show depth measured at $60 \mathrm{~s}$ intervals; grey boxes: nighttime 


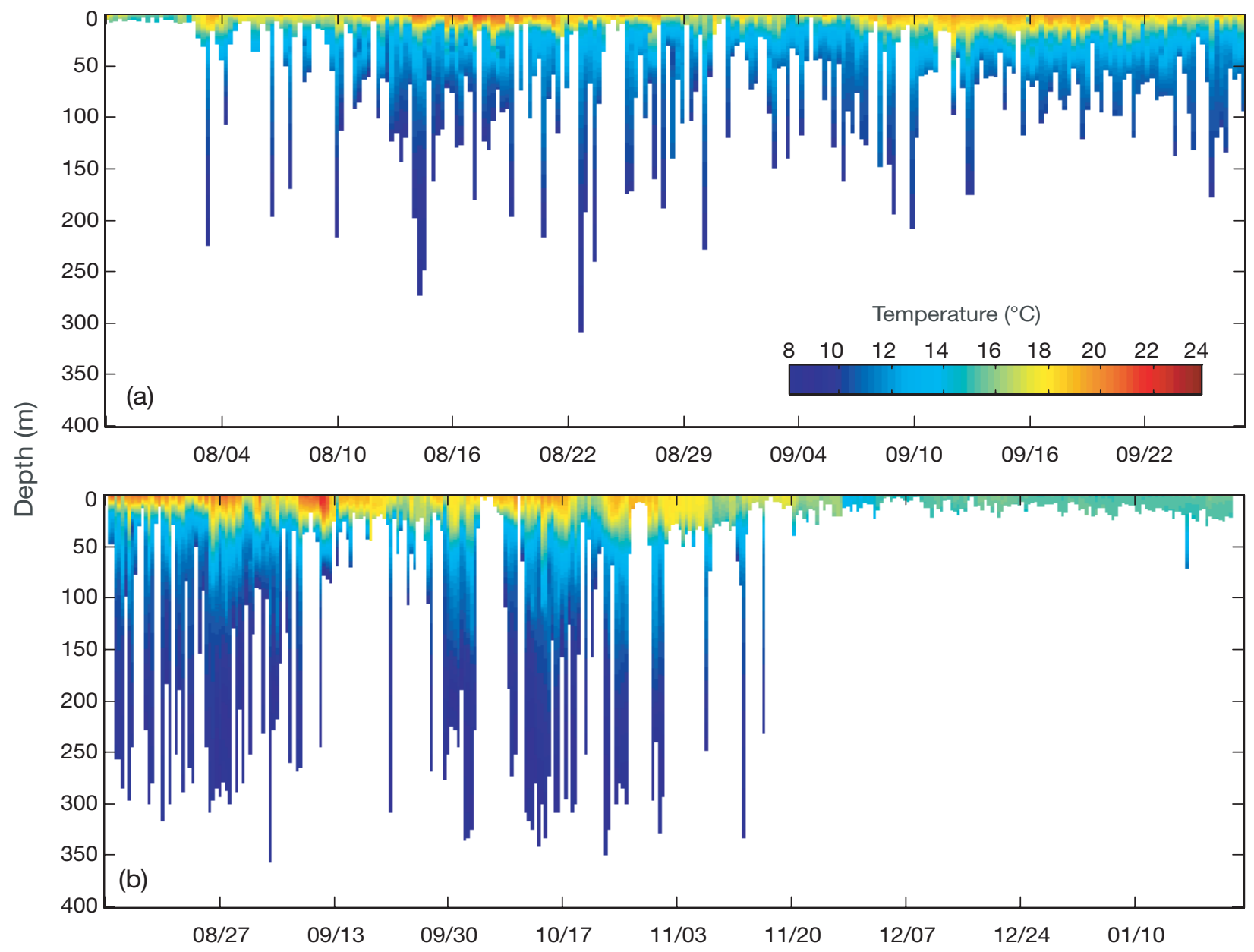

Fig. 9. Carcharodon carcharias. Time series of water column thermal structure for (a) Shark YOY-2 and (b) Shark 3YR-1. Extent of the profile: maximum depth reached on a given day. Color denotes ambient water temperature

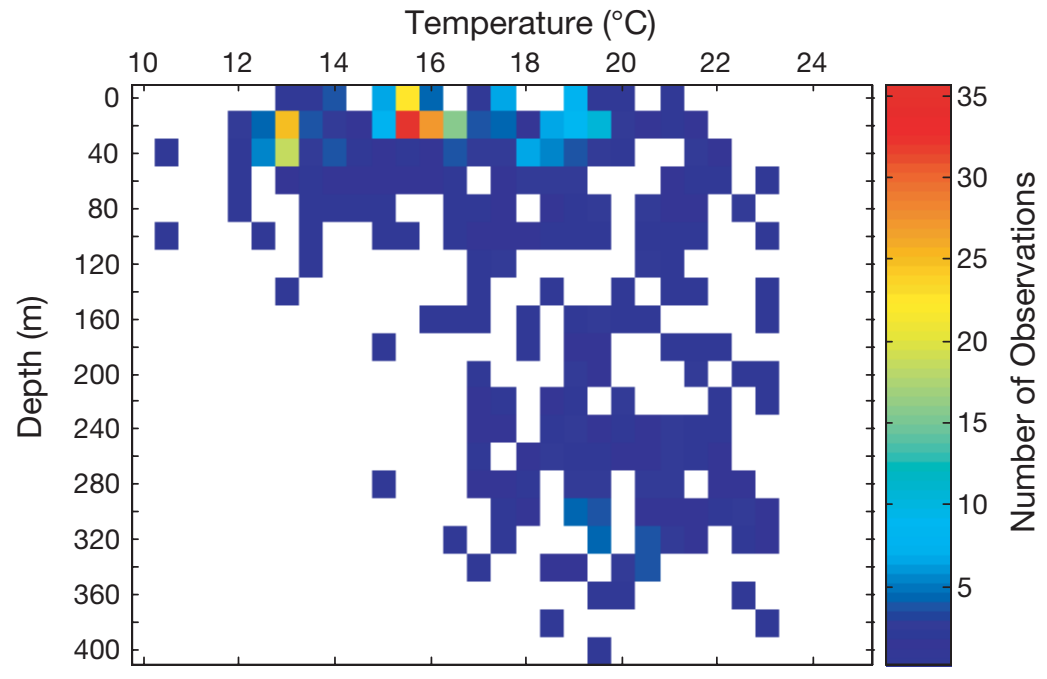

Fig. 10. Carcharodon carcharias. Frequency of depth-temperature observations for two 3 yr olds (3YR-1, 3YR-2). Color denotes number of observations at each depth and temperature correlated with surface temperature (least squares regression, $\mathrm{r}^{2}=32.7, \mathrm{p}<$ 0.01).

\section{Bycatch of juvenile white sharks in fisheries}

In this study, 4 YOY white sharks were caught in US and Mexican bottom-set gillnets 6 times (Table 1). All YOY sharks were initially captured in gillnets and 2 sharks (YOY-1 and YOY4) encountered gillnets a second time. Shark YOY-1 encountered a gillnet near Ventura, California, USA and escaped, but left its satellite tag behind in the net. Shark YOY-4 was recaptured by a gillnet fisherman near Ensenada, Baja California, Mexico. 


\section{DISCUSSION}

\section{Nursery region of white sharks in the eastern Pacific}

In this study we tracked 6 juvenile white sharks in the eastern North Pacific over durations of 24 to $182 \mathrm{~d}$ and have provided new information on their seasonal movements, behavior and habitat utilization. The apparent residency of sharks in the California Current system off California and Baja California suggests that this region is an important nursery habitat for juvenile white sharks (Fig. 1). YOY sharks tracked during summer (Sharks YOY-1 and YOY-2) remained within the Southern California Bight (SCB), whereas YOY sharks tracked in autumn (YOY-3 and YOY-4) moved south into waters of Baja California, Mexico. The two 3 yr old sharks were tracked from late summer through winter, with one remaining in the SCB and northern Baja California waters (Shark 3YR-2), overlapping the range of the YOY sharks, and the other moving north of Point Conception into central and northern California waters (Shark 3YR-1).

The results presented here extend the nursery region for white sharks south of the $\mathrm{SCB}$, expanding the area described by Klimley (1985), and indicating that juvenile white sharks located in US and Mexican waters are most likely part of the same population. Juvenile white sharks have also been captured inside the Gulf of California (Klimley 1985, O. Sosa-Nishizaki pers. comm.). Our results suggest that the expansion of the nursery may be associated with season, as YOY sharks tracked in the summer remained in the SCB, while those tracked in the autumn moved south into Mexican waters. Longer tracks are required to determine the full extent of the nursery grounds in the eastern Pacific and whether subpopulations exist.

Putative nursery areas exist in other regions of the world, and in both the northern and southern hemispheres, captures of pregnant and YOY sharks occur most frequently during spring and summer (Casey \& Pratt 1985, Bruce 1992, Cliff et al. 1996, Fergusson 1996, Francis 1996, Uchida et al. 1996). In our study, sea surface temperatures occupied by YOY sharks ranged from 15.0 to $23.4^{\circ} \mathrm{C}$. For the seasons of YOY and pregnant shark captures in other putative nursery areas, climatological temperatures are 19 to $22^{\circ} \mathrm{C}$ in southern Japan; 20 to $22^{\circ} \mathrm{C}$ in Taiwan; 21 to $26^{\circ} \mathrm{C}$ in eastern South Africa; 20 to $23^{\circ} \mathrm{C}$ in southeastern Australia; 16 to $20^{\circ} \mathrm{C}$ in northern New Zealand; 20 to $26^{\circ} \mathrm{C}$ in the central Mediterranean; and 17 to $24^{\circ} \mathrm{C}$ in the Mid-Atlantic Bight (Anonymous 2005). The similarity in water temperature in all of these regions suggests that there may be an optimal thermal environment for YOY white sharks.
Larger juvenile white sharks appear to have a different geographic range and seasonal pattern than YOY animals. While both year classes of sharks appear to enter Mexican waters at various points, 3 yr old individuals returned to California waters and remained there during the winter. Shark 3YR-2 moved north of Point Conception, into the primary nearshore habitat of adult white sharks. Since this individual was a $3 \mathrm{yr}$ old of $2.5 \mathrm{~m}$ length, and fish predominate in the diets of white sharks $<3 \mathrm{~m}$ in length (Tricas \& McCosker 1984), the northward movements of juvenile sharks are probably not associated with the addition of mammals to the diet (Klimley 1985). Differences in track duration may bias the geographic ranges covered (Block et al. 2005), so longer tracks on YOY sharks may show more overlap with the 3 yr old sharks. Conversely 3 yr old sharks may be revealing a niche expansion to the north that YOY sharks cannot physiologically tolerate (Weng et al. 2005).

\section{Accuracy of geopositions}

Long distance movements of individual sharks between the SCB, Baja California, and northern California were demonstrated by satellite-derived pop-up endpoint positions and recapture positions, with intermediate positions calculated using light and SST based geolocation. The geoposition errors for juvenile white sharks in this study $(54 \pm 15 \mathrm{~km}$ zonally, $231 \pm 64 \mathrm{~km}$ meridionally; Fig. 2) meant that the data were useful in characterizing movements out of the SCB, but not within the SCB. As in the validation study of Teo et al. (2004), longitude errors for juvenile white sharks are smaller than latitude errors. However, the latitude errors for juvenile white sharks are all to the south, indicating a systematic bias which was not observed by Teo et al. (2004). The use of SST to determine latitude (Smith \& Goodman 1986) is most accurate in regions where greater north-south gradients in SST exist; the gradient is monotonic over scales greater than a degree of latitude; there are no large gaps in SST data, as occur in areas with high cloud cover or near land; and the scale of movements is much larger than the scale of errors. Teo et al. (2004) estimated root mean square latitude errors of $163 \mathrm{~km}, 129 \mathrm{~km}$ and $100 \mathrm{~km}$ for salmon sharks Lamna ditropis, blue sharks Prionace glauca and bluefin tuna Thunnus thynnus, respectively. These highly migratory pelagic species travel hundreds or thousands of kilometers in primarily offshore waters. The present study takes place in coastal, upwelled waters with a much finer scale of variability in SST, which most likely explains the slightly higher error estimates we obtained. Furthermore, the high cloud cover in the region reduces the coverage of satellite data. 


\section{Diel patterns in depth and temperature}

The $30 \mathrm{~s}$ and $60 \mathrm{~s}$ archival data sets obtained from 4 white sharks provided the opportunity to conduct a detailed analysis of behavior over diel and lunar time scales, across a range of habitats. Juvenile white sharks make deeper vertical movements during day, dawn and dusk than during night (Figs. 3 \& 4). Dewar et al. (2004) also noted a peak in activity in a juvenile white shark in the SBC at sunrise. Twilight activity has been noted in a wide range of pelagic fishes including tunas (Thunnini) (Dagorn et al. 2000, Kitagawa et al. 2000, Schaefer \& Fuller 2002), billfishes (Xiphidae, Istiophoridae) (Carey \& Robison 1981, Holland et al. 1990a) and mako sharks Isurus oxyrinchus (Sepulveda et al. 2004). Stomach content analysis indicates that these dawn/dusk activity peaks are often associated with feeding (Buckley \& Miller 1994, Scott \& Cattanach 1998), although feeding may also occur during the day (Reintjes \& King 1953) or night (Holland et al. 1990b). Vertical excursions into the thermocline comprise a small portion of the animals' time, but may be ecologically important if they constitute foraging behavior. Sepulveda et al. (2004) used stomach temperature data to confirm feeding events on vertical excursions by mako sharks. Similar studies on juvenile white sharks would help to confirm whether this behavior is for foraging.

During the nighttime, the moon phase influenced the occurrence and depth of vertical excursions by juvenile white sharks (Fig. 8). Vertical excursions into the thermocline occurred more frequently and to greater depths during full moon nights as compared to new moon nights. Increased depth during full moon periods may be associated with the deeper depth of the prey species (squids, fishes, zooplankton), which undergo light-mediated vertical migrations (Ringelberg \& van Gool 2003). This also suggests that during the full moon, the juvenile white sharks are foraging at night.

\section{Depth and temperature preferences}

Tagging data indicate that the primary habitat of juvenile white sharks is in the surface mixed layer, but that they make extensive use of the cooler waters of the thermocline. The preference for surface mixed layer waters results in occupancy of the warmest waters within the California Current, ranging from 16 to $20^{\circ} \mathrm{C}$ (Figs. $5 \& 6$ ). This habitat preference is similar to those of the sharks tracked by Klimley et al. (2002) and Dewar et al. (2004), which showed a preference for waters of 15 to 21 and 16 to $22^{\circ} \mathrm{C}$ respectively. These temperatures are characteristic of nearshore SCB waters during summer and autumn (Venrick et al.
2003). Occupancy of cooler waters in the thermocline by juvenile white sharks was higher in this study than in previous studies. During summer and autumn, YOY white sharks spent $32 \pm 20 \%$ of their time in waters cooler than $16^{\circ} \mathrm{C}$, as compared to $11 \%$ of the time for the white shark tracked by Dewar et al. (2004) and $25 \%$ by the white shark tracked by Klimley et al. (2002). The greater occupancy of cooler waters observed here likely results from the longer tracks capturing a wider variety of behavior: $46 \pm 19 \mathrm{~d}$ in the present study, vs. 0.15 and $28 \mathrm{~d}$ in the studies of Klimley et al. (2002) and Dewar et al. (2004), respectively. The lack of data for YOY sharks during the winter leaves open the possibility that this age class may encounter cooler habitats if tracked during this period.

The 3 yr old sharks tracked in this study inhabited similar water masses to the YOY sharks during summer and autumn, but utilized the habitat differently. These older and larger sharks made deeper vertical excursions, and as a result, their depth distributions were significantly deeper (Fig. 4) and temperature distributions significantly cooler (Fig. 6). A similar result was found for juvenile mako sharks by Sepulveda et al. (2004). The niche expansion of white sharks into cooler habitats appears to continue beyond the 3 yr old phase, as adult white sharks occupy waters ranging from 4 to $25^{\circ} \mathrm{C}$ (Lowe \& Goldman 2001, Boustany et al. 2002) and enter boreal habitats (Martin 2004).

\section{Foraging habitat of juvenile white sharks}

The large proportion of time juvenile white sharks spent in the surface mixed layer indicates that this may be an important foraging habitat. Stomach content analysis shows that nearshore pelagic fishes are in the diet of juvenile white sharks, including Pacific sardine Sardinops sagax, king salmon Oncorhynchus tshawytscha, white seabass Cynoscion nobilis and striped bass Morone saxatilis (Klimley 1985). Other potential prey species that inhabit the water column in the study area include grunion Leuresthes tenuis, surfperch Hyperprosopon spp., smelt Atherinops spp., croaker Genyonemus spp., mackerel Scomber spp., barracuda Sphyraena argentea and market squid Loligo opalescens.

Our data indicate that benthic foraging is also important for juvenile white sharks (Fig. 8b). Behavior indicating benthic foraging was observed on $63 \pm 10 \%$ of all days for sharks with archival records. Similar behaviors were noted by Dewar et al. (2004), and stomach content studies show a variety of demersal fishes in the diet of juvenile white sharks including the bat ray Myliobatis californica, cabezon Scorpaenichthys marmoratus, soupfin shark Galeorhinus zygopterus, grey smooth-hound Mustelus californicus, spiny dogfish 
Squalus acanthius, lingcod Ophiodon elongatus, rock crab Cancer antennarius, and rockfish Sebastes spp. (Klimley 1985). The secondary peak of occupancy at depth $(47+23 \mathrm{~m}$ for YOY sharks, Fig. 3; $240 \mathrm{~m}$ for $3 \mathrm{yr}$ olds, Fig. 4) is the aggregate time of vertical excursions and may be an indicator of foraging effort. There are large depth-associated changes in the species assemblages of fishes off California and Baja California, so the depth range of a predator determines the forage species it can access. At the depth range of the secondary occupancy peak for YOY sharks, other potential forage species include shallow-living soft-substrate demersal fishes such as halibut Paralichthys californicus, sanddabs Citharichthys spp; shallow hard-substrate fishes such as copper rockfish Sebastes caurinus, vermilion rockfish $S$. miniatus, lingcod Ophiodon elongatus and painted greenling Oxylebius pictus; or elasmobranches such as round stingray Urobatis halleri, California skate Raja inornata and leopard shark Triakis semifasciata (Bond et al. 1999, Love et al. 2000). Forage species accessible to $3 \mathrm{yr}$ old sharks could include deeper-living soft-substrate fishes such as turbot Hypsopsetta spp., Pleuronichthys spp. and sole Microstomus spp., and deep-living hard-substrate fishes such as greenspotted rockfish $S$. cholorostictus, flag rockfish $S$. rubrivinctus and bocaccio $S$. pausispinus (Bond et al. 1999, Love et al. 2000).

The closely related shortfin mako shark, which is abundant in the SCB, appears to utilize thermocline waters less than juvenile white sharks. Shortfin mako sharks of a size intermediate between YOY and $3 \mathrm{yr}$ old sharks in this study $(1.8 \mathrm{~m})$, tracked in waters of the $\mathrm{SCB}$, showed only occasional use of the thermocline and spent only $3.7 \pm 3.2 \%$ of the time in waters cooler than $16^{\circ} \mathrm{C}$ (Holts \& Bedford 1993). This suggests that there may be some resource partitioning between these species, with mako sharks utilizing epipelagic resources and white shark potentially making use of both epipelagic and demersal resources.

\section{Thermal limitation of habitat}

A number of results in this study are consistent with thermal limitation in juvenile white shark habitat utilization, and a niche expansion into cooler habitats with growth. The southward movement of YOY animals during the autumn, when mixed layer temperatures in the SCB are falling, is consistent with movements to avoid cooler winter temperatures. The greater depths and cooler temperatures of vertical excursions undertaken by 3 yr olds, in comparison to YOY sharks occupying the same region during the same season (summer and autumn in the SCB), are consistent with an expansion of thermal habitat with body size. The northward movement of one 3 yr old shark into waters north of Point Conception, where YOY individuals are rare (Klimley 1985), is consistent with a thermally mediated geographic range expansion with body size. The cessation of excursions into the thermocline by 3 yr old sharks when surface mixed layer temperatures fall below $16^{\circ} \mathrm{C}$ is consistent with behavioral thermoregulation (Carey \& Scharold 1990, Holland et al. 1992). However, the observation could also be explained by patterns in the vertical distribution of prey. It is important to note the bias caused by the longer tracks of $3 \mathrm{yr}$ olds, extending into the winter, as compared to the tracks of YOY sharks that were limited to summer and autumn. However, comparisons of depth and temperature using only data for summer and autumn did reveal deeper and cooler habitat utilization by 3 yr olds.

Recent physiological studies have indicated that pelagic fish may have cardiac limitations when entering cold waters. A cold induced bradycardia is evident in tunas (Korsmeyer et al. 1997, Blank et al. 2002, 2004). Although few studies have investigated the influence of cooler temperatures on in vivo cardiac performance in lamnid sharks, it is possible that a similar cold-induced bradycardia occurs. We have identified a high expression of calcium cycling proteins in the cardiac myocyctes of lamnid sharks including the white shark (Weng et al. 2005). These results suggest that white sharks have the potential to maintain cardiac output at cooler temperatures, but the relation of this capacity to body size remains unknown.

\section{Fishing mortality and management}

In this study, 4 juvenile white sharks were captured by US and Mexican fishermen 6 times. Dewar et al. (2004) reported that a single juvenile white shark was captured twice in the SCB. The capture rate of juvenile white sharks in bottom-set gillnet fisheries in US and Mexican waters suggests that fishing mortality on juvenile white sharks in the Eastern Pacific may be significant and that management actions may be warranted to protect these vulnerable life history stages. Efforts to reduce fishing mortality will be most effective if management efforts occur in both US and Mexican waters.

The geographic range of species and individuals is important in understanding population dynamics (DeMartini 1993, McNeill \& Fairweather 1993, Russ \& Alcala 1996). Futhermore, the fisheries that animals are likely to encounter, and the required scale of management actions, changes with ontogeny and season (Block et al. 2005). In addition to understanding geographic range, knowing the vertical distribution of 
animals in the water column allows assessment of the vulnerability of juvenile white sharks to different types of fishing gear. Vertical habitat data showing a preference for the surface mixed layer and upper thermocline indicate that juvenile white sharks may be most susceptible to fishing gear deployed at these depths. Furthermore, the diel pattern showing greater vertical movements during daylight indicates that they are more likely to be captured in bottom-set gillnets during daylight, as noted by Dewar et al. (2004). This implies that a shift toward nocturnal gillnet effort could reduce bycatch of juvenile white sharks. In regions where mixed layer temperatures are cooler than $16^{\circ} \mathrm{C}$, juvenile white sharks rarely make vertical excursions and thus should be less vulnerable to deeper gear. Northward movements of larger juveniles may reduce the risk of encountering bottom set gillnets, as this gear is presently banned north of Point Conception, California.

Acknowledgements. This research was supported by grants from the Monterey Bay Aquarium Foundation and the Office of Naval Research. We thank the following for assistance with this study: K. Bates, S. Reid, J. Welsh, M. Ezcurra, T. Athens, J. Vaudo, D. Topping, M. Blasius, L. Hale, L. Bellquist, K. Johnson, T. Price, K. Anthony, Y. Papastamatiou, C. Williams, T. Wilmarth, N. Guglielmo, B. Henke, M. Schmidt, C. Espinoza, C. Spencer, S. Robledo Ruiz, R. Robledo Ornelas, O. SosaNishizaki, R. Hamilton, C. Farwell, C. Harrold, J. Ganong, R. Matteson, M. Castleton, S. Teo, A. Boustany, D. Kohrs and G. Strout.

\section{LITERATURE CITED}

Anonymous (1999) Proposal to include Carcharodon carcharias (Great White Shark) on Appendix I of the Convention of International Trade in Endangered Species of Wild Fauna and Flora. Report No. 11.48, CITES, Geneva

Anonymous (2005) World Ocean Atlas. National Oceanographic Data Center, Silver Spring, MD

Anonymous (2006) Astronomical Almanac Online. US Naval Observatory, Washington, and HM Nautical Almanac Office, Didcot

Blank J, Morrisette J, Davie P, Block BA (2002) Effects of temperature, epinephrine and $\mathrm{Ca}^{2+}$ on the hearts of yellowfin tuna (Thunnus albacares). J Exp Biol 205:1881-1888

Blank JM, Morrissette JM, Landeira-Fernandez AM, Blackwell SB, Williams TD, Block BA (2004) In situ cardiac performance of Pacific bluefin tuna hearts in response to acute temperature change. J Exp Biol 207:881-890

Block BA, Teo SLH, Walli A, Boustany A and 5 others (2005) Electronic tagging and population structure of Atlantic bluefin tuna. Nature 434:1121-1127

Bond AB, Stephens JS, Pondella DJ, Allen MJ, Helvey M (1999) A method for estimating marine habitat values based on fish guilds, with comparisons between sites in the Southern California Bight. Bull Mar Sci 64:219-242

Bonfil R, Meyer M, Scholl MC, Johnson R and 5 others (2005) Transoceanic migration, spatial dynamics, and population linkages of white sharks. Science 310:100-103

Boustany AM, Davis SF, Pyle P, Anderson SD, Le Boeuf BJ, Block BA (2002) Satellite tagging: Expanded niche for white sharks. Nature 415:35-36

Bruce BD (1992) Preliminary observations on the biology of the white shark Carcharodon carcharias in South Australian Waters. Aust J Mar Freshw Res 43:1-11

Buckley TW, Miller BS (1994) Feeding habits of yellowfin tuna associated with fish aggregation devices in American Samoa. Bull Mar Sci 55:445-459

Cailliet GM, Natanson LJ, Welden BA, Ebert DA (1985) Preliminary studies on the age and growth of the white shark, Carcharodon carcharias, using vertebral bands. Mem South Calif Acad Sci 9:49-60

Carey F, Robison B (1981) Daily patterns in the activities of swordfish, Xiphias gladius, observed by acoustic telemetry. Fish Bull 79:277-292

Carey FG, Scharold JV (1990) Movements of blue sharks (Prionace glauca) in depth and course. Mar Biol 106:329-342

Carey FG, Kanwisher JW, Brazier O, Gabrielson G, Casey JG, Pratt HLJ (1982) Temperature and activities of a white shark, Carcharodon carcharias. Copeia 1982:254-260

Casey JG, Pratt HL Jr (1985) Distribution of the white shark, Carcharodon carcharias, in the western North Atlantic. Mem South Calif Acad Sci 9:2-14

Cliff G, Dudley SFJ, Jury MR (1996) Catches of white sharks in KwaZulu-Natal, South Africa and environmental influences. In: Klimley AP, Ainley DG (eds) Great white sharks: the biology of Carcharodon carcharias. Academic Press, San Diego, CA, p 351-362

Compagno LJV (1984) Vol. 4 Sharks of the World, Part 1 Hexanchiformes to Lamniformes. United Nations Development Programme, Rome

Dagorn L, Bach P, Josse E (2000) Movement patterns of large bigeye tuna (Thunnus obesus) in the open ocean, determined using ultrasonic telemetry. Mar Biol 136:361-371

DeMartini E (1993) Modeling the potential of fishery reserves for managing Pacific coral reef fishes. Fish Bull 91: $414-427$

Dewar H, Domeier M, Nasdy-Lucas N (2004) Insights into young of the year white sharks (Carcharodon carcharias) behavior in the Southern California Bight. Environ Biol Fishes 70:133-143

Fergusson IK (1996) Distribution and autecology of the white shark in the eastern North Atlantic Ocean and the Mediterranean Sea. In: Klimley AP, Ainley DG (eds) Great white sharks: the biology of Carcharodon carcharias. Academic Press, CA, p 321-345

Fergusson IK, Compagno LJV, Marks MA (2000) Predation by white sharks, Carcharodon carcharias (Chondrichthyes: Lamnidae) upon chelonians, with new records from the Mediterranean Sea and a first record of the ocean sunfish Mola mola (Osteichthyes: Molidae) as stomach contents. Environ Biol Fishes 58:447-453

Francis MP (1996) Observations on a pregnant white shark with a review of reproductive biology. In: Klimley AP, Ainley DG (eds) Great white sharks: the biology of Carcharodon carcharias. Academic Press, San Diego, CA, p 157-172

Goldman KJ (1997) Regulation of body temperature in the white shark, Carcharodon carcharias. J Comp Physiol B Biochem Syst Environ Physiol 167:423-429

Goldman KJ, Anderson SD, McCosker JE, Klimley AP (1996) Temperature, swimming depth, and movements of a white shark at the South Farallon Islands, California. In: Klimley AP, Ainley DG (eds) Great white sharks: the biology of Carcharodon carcharias. Academic Press, San Diego, CA, p 111-120

Hill RD, Braun MJ (2001) Geolocation by light-level. The next step: latitude. In: Sibert J, Nielson J (eds) Electronic 
tagging and tracking in marine fisheries research: methods and technologies, Vol 1. Kluwer Academic Press, Dordrecht, p 315-330

Holland K, Brill R, Chang R (1990a) Horizontal and vertical movements of Pacific blue marlin captured and released using sportfishing gear. Fish Bull 88:397-402

Holland K, Brill R, Chang R (1990b) Horizontal and vertical movements of yellowfin and bigeye tuna associated with fish aggregating devices. Fish Bull 88:493-507

Holland K, Brill R, Chang R, Sibert J, Fournier D (1992) Physiological and behavioural thermoregulation in bigeye tuna (Thunnus obesus). Nature 358:410-412

Holts D, Bedford D (1993) Horizontal and vertical movements of the shortfin mako shark, Isurus oxyrinchus, in the southern California bight. Aust J Mar Freshw Res 44: 901-909

Inskipp T, Gillett HJ (eds) (2005) Checklist of CITES species and Annotated CITES Appendices and reservations. CITES Secretariat, Geneva, Switzerland \& UNEP-WCMC, Cambridge, UK. Available at: www.cites.org/eng/ resources/publications.shtml

Kitagawa T, Nakata H, Kimura S, Itoh T, Tsuji S, Nitta A (2000) Effect of ambient temperature on the vertical distribution and movement of Pacific bluefin tuna Thunnus thynnus. Mar Ecol Prog Ser 206:251-260

Klimley AP (1985) The areal distribution and autecology of the white shark, Carcharodon carcharias, off the West Coast of North America. Mem South Calif Acad Sci 9:15-40

Klimley AP, Le Boeuf BJ, Cantara KM, Richert JE, Davis SF, Van Sommeran S, Kelly JT (2001) The hunting strategy of white sharks (Carcharodon carcharias) near a seal colony. Mar Biol 138:617-636

Klimley A, Beavers S, Curtis T, Jorgensen S (2002) Movements and swimming behavior of three species of sharks in La Jolla Canyon, California. Environ Biol Fishes 63: $117-135$

Kohler NE, Casey JG, Turner PA (1995) Length-weight relationships for 13 species of sharks from the western North Atlantic. Fish Bull 93:412-418

Korsmeyer KE, Lai NC, Shadwick RE, Graham JB (1997) Heart rate and stroke volume contributions to cardiac output in swimming yellowfin tuna: response to exercise and temperature. J Exp Biol 20:1975-1986

Love MS, Caselle JE, Snook L (2000) Fish assemblages around seven oil platforms in the Santa Barbara Channel area. Fish Bull 98:96-117

Lowe CG, Goldman KJ (2001) Thermal and bioenergetics of elasmobranchs: bridging the gap. Environ Biol Fishes 60: 251-266

Martin RA (2004) Northerly distribution of white sharks, Carcharodon carcharias, in the eastern Pacific and relation to ENSO events. Mar Fish Rev 66:16-28

McNeill S, Fairweather P (1993) Single large or several small marine reserves? An experimental approach with seagrass fauna. J Biogeogr 20:429-440

Mollet HF, Cailliet GM (2002) Comparative population demography of elasmobranchs using life history tables,
Leslie matrices and stage-based matix models. Mar Freshw Res 53:503-516

Rao RR, Molinari RL, Festa JF (1989) Evolution of the climatological near-surface thermal structure of the tropical Indian Ocean: 1. Description of mean monthly mixed layer depth, and sea surface temperature, surface current, and surface meteorological fields. J Geophys Res C 94: 10801-10815

Reintjes JW, King JE (1953) Food of yellowfin tuna in the Central Pacific. Fish Bull 54:91-110

Ringelberg J, van Gool E (2003) On the combined analysis of proximate and ultimate aspects in diel vertical migration (DVM) research. Hydrobiologia 491:85-90

Russ G, Alcala A (1996) Do marine reserves export adult fish biomass? Evidence from Apo Island, central Philippines. Mar Ecol Prog Ser 132:1-9

Schaefer KM, Fuller DW (2002) Movements, behavior, and habitat selection of bigeye tuna (Thunnus obesus) in the eastern equatorial Pacific, ascertained through archival tags. Fish Bull 100:765-788

Scott MD, Cattanach KL (1998) Diel patterns in aggregations of pelagic dolphins and tunas in the eastern Pacific. Mar Mamm Sci 14:401-428

Sepulveda CA, Kohin S, Chan C, Vetter R, Graham JB (2004) Movement patterns, depth preferences, and stomach temperatures of free-swimming juvenile mako sharks, Isurus oxyrinchus, in the Southern California Bight. Mar Biol 145: 191-199

Smith P, Goodman D (1986) Determining fish movements from an 'archival' tag: precision of geographical positions made from a time series of swimming temperature and depth. Report No. SWFC-60, NOAA Tech Memo NMFS SWFC-60, La Jolla, CA

Stevens J, Bonfil R, Dulvy N, Walker P (2000) The effects of fishing on sharks, rays, and chimaeras (chondrichthyans), and the implications for marine ecosystems. ICES J Mar Sci 57:476-494

Teo SLH, Boustany A, Blackwell S, Walli A, Weng KC, Block BA (2004) Validation of geolocation estimates based on light level and sea surface temperature from electronic tags. Mar Ecol Prog Ser 283:81-98

Tricas TC, McCosker JE (1984) Predatory behavior of the white shark (Carcharodon carcharias), with notes on its biology. Proc Cal Acad Sci 43:221-238

Uchida S, Toda M, Teshima K, Yano K (1996) Pregnant white sharks and full-term embryos from Japan. In: Klimley AP, Ainley DG (eds) Great white sharks: the biology of Carcharodon carcharias. Academic Press, San Diego, CA, p 139-155

Venrick E, Bograd SJ, Checkley D, Durazo R and 10 others (2003) The state of the California Current, 2002-2003: tropical and subarctic influences vie for dominance. Calif Coop Ocean Fish Invest Rep 44:28-60

Weng KC, Castilho PC, Morrissette JM, Landiera-Fernandez A and 4 others (2005) Satellite tagging and cardiac physiology reveal niche expansion in salmon sharks. Science 310:104-106

Submitted: April 8, 2006; Accepted: September 21, 2006 Proofs received from author(s): April 19, 2007
Editorial responsibility: Rory Wilson (Contributing Editor), Swansea, UK 